\title{
Bruxism in children and transverse plane of occlusion: Is there a relationship or not?
}

\author{
Ana Carla Raphaelli Nahás-Scocate ${ }^{1}$, Fernando Vusberg Coelho², Viviane Chaves de Almeida ${ }^{3}$
}

\begin{abstract}
Objective: To assess the occurrence of bruxism in deciduous dentition and a potential association between the habit and the presence or absence of posterior crossbite. Methods: A total of 940 patient files were assessed. They were gathered from the archives of University of São Paulo City - UNICID; however, 67 patient files were dismissed for not meeting the inclusion criteria. Therefore, 873 children, males and females, comprised the study sample. They were aged between 2-6 years old and came from six different public primary schools from the east of the city of São Paulo. Data were collected through questionnaires answered by parents/guardians and by clinical examinations carried out in the school environment in order to obtain the occlusal characteristics in the transverse direction. First, a descriptive statistical analysis of all variables was performed (age, sex, race, posterior crossbite, bruxism, headache and restless sleep); then, the samples were tested by means of chi-square test with significance level set at $0.05 \%$. A logistic regression model was applied to identify the presence of bruxism. Results: The prevalence of this parafunctional habit was of $28.8 \%$, with $84.5 \%$ of patients showing no posterior crossbite. Regarding the association of bruxism with crossbite, significant results were not found. Children with restless sleep have 2.1 times more chances of developing bruxism, whereas children with headache have 1.5 more chances. Conclusion: Transverse plane of occlusion was not associated with the habit of bruxism.
\end{abstract}

Keywords: Malocclusion. Bruxism. Epidemiology.

Introdução: avaliar a prevalência de bruxismo na dentadura decídua e a associação existente entre este hábito e a presença ou não de mordida cruzada posterior. Métodos: foram avaliados 940 prontuários do arquivo de documentações da Universidade Cidade de São Paulo (UNICID), sendo que 67 foram excluídos por não atenderem aos critérios de inclusão. Logo, 873 , de ambos os sexos, na faixa etária de 2 a 6 anos, procedentes de seis escolas municipais de educação infantil da zona leste da cidade de São Paulo, compuseram a amostra desse estudo. Os dados foram coletados por meio de questionários respondidos pelos pais/responsáveis e exames clínicos, realizados em ambiente escolar, para obtenção das características oclusais no sentido transversal. Primeiramente, efetuou-se uma análise estatística descritiva de todas as variáveis avaliadas na amostra (idade, sexo, raça, mordida cruzada posterior, bruxismo, dor de cabeça e sono agitado) e, em seguida, utilizou-se o teste qui-quadrado, com grau de significância de $0,05 \%$, e um modelo de regressão logística para a presença do bruxismo. Resultados: a prevalência desse hábito parafuncional foi de $28,8 \%$ do total da amostra, e $84,5 \%$ não apresentaram mordida cruzada posterior. Quanto à associação de bruxismo com a mordida cruzada posterior, não foram encontrados resultados significativos. Verificou-se, também, que as crianças com sono agitado possuem 2,1 vezes mais chances de desenvolver o bruxismo e, as com dor de cabeça, 1,5 vezes. Conclusão: o plano transversal de oclusão não apresentou relação com o hábito do bruxismo.

Palavras-chave: Má oclusão. Bruxismo. Epidemiologia.

${ }^{1}$ Associate professor, Undergraduate and Postgraduate Program in Orthodontics, University of São Paulo City - UNICID.

${ }^{2}$ DDS, UNICID.

${ }^{3} \mathrm{MSc}$ in Orthodontics, UNICID.

" The authors report no commercial, proprietary or financial interest in the products or companies described in this article.
How to cite this article: Nahás-Scocate ACR, Coelho FV, Almeida VC. Bruxism in children and transverse plane of occlusion: Is there a relationship or not? Dental Press J Orthod. 2014 Sept-Oct;19(5):67-73. DOI: http://dx.doi. org/10.1590/2176-9451.19.5.067-073.oar

Submitted: January 10, 2013 - Revised and accepted: August 31, 2013

Contact address: Ana Carla Raphaelli Nahás-Scocate

Rua Cesário Galeno, 448/475 - Tatuapé - São Paulo/SP — Brazil

CEP: 03071-000 - E-mail: carlanahas@yahoo.com.br 


\section{INTRODUCTION}

Bruxism is a parafunctional activity of the masticatory system characterized by clenching or grinding the teeth with rhythmic muscular contractions more frequent during sleep. ${ }^{28}$ While this parafunctional activity is performed, nearly entirely in the subconscious level, neuromuscular protection mechanisms are absent, ${ }^{19}$ thereby changing the masticatory system and causing temporomandibular disorders. ${ }^{29}$

Clinically, bruxism in children not only causes different levels of tooth surface wear, but also provides patients with muscle and joint discomfort. Furthermore, due to axial forces generated in patient's teeth, it can act as an adjuvant in the progression of destructive periodontal disease in children, ${ }^{2}$ in addition to contributing to the development of false Class III, accelerated root resorption of deciduous teeth, changes in the chronology of permanent teeth irruption and promotion of dental crowding. ${ }^{15}$ Thus, this habit should be diagnosed and managed as early as possible. ${ }^{15}$

There have been only a few published studies conducted to assess the prevalence of bruxism in children. This limitation prevents scientific parameters and association of bruxism with etiological factors to be established. The literature appears to be contradictory regarding the etiology of this parafunctional habit in childhood, thereby characterizing its origin as multifactorial, involving heredity, psychological and behavioral factors as well as occlu-

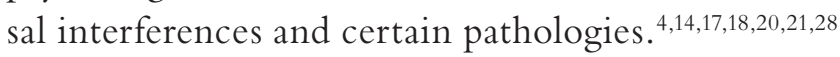
Some authors report that occlusal factors such as overjet, overbite, molar and canine relationship, open bite and crossbite might play an important role in the development of this habit in children. ${ }^{12,26,29}$

Bruxism in children is also diagnosed with painful symptoms of Temporomandibular Disorders (TMD) of which it can be considered a possible causal factor. ${ }^{26}$ Additionally, frequent headaches and restless sleep are associated with this habit. ${ }^{3}$

Thus, in this context, this study aimed at investigating the prevalence of bruxism in deciduous dentition, trying to relate it to occlusal factors, specifically the transverse plane of occlusion, so as to establish a causal factor alone, since several nuances are present in scientific research. In addition, the association of this parafunctional habit with restless sleep and headaches was also verified.

\section{MATERIAL AND METHODS}

\section{Ethical aspects}

This study was funded by the Brazilian National Council for Scientific and Technological Development - CNPq (Undergraduate Research) from 2008 to 2009. It is part of a project developed to assess the association between bruxism in children and posterior crossbite, conducted in accordance with the rules and principles adopted by Ethics and Research (13355774).

\section{Sample selection}

Clinical records of Brazilian children, males and females, aged between 2 years and 1 month old and 6 years and 11 months old, enrolled in 2005 in primary public schools located in the east of the city of São Paulo, were assessed. The initial sample comprised 940 children; however, 67 records were excluded for not meeting the inclusion criteria. Therefore, the final sample comprised 873 children of which 37.3\% and $38.7 \%$ were 4 and 5 years old, respectively.

\section{Inclusion criteria}

The medical records of children included in this sample met the following inclusion criteria: Informed consent form signed by parents/guardians; questionnaire properly answered; children aged between 2 years and 1 month and 6 years and 11 months; complete deciduous dentition without erupted or erupting permanent teeth; absence of carious lesions or extensive loss of structure that compromised coronary occlusion; lack of early loss of deciduous teeth; absence of any kind of trauma; absence of visual and/or hearing and/or mental impairment; no previous orthodontic treatment and/or speech therapy.

\section{Informed consent form and questionnaire}

Parents/guardians were given detailed explanation about the objectives and design of data collection in the schools. Subsequently, an informed consent form was sent so as to notify them about the research, its importance and objectives. A questionnaire on parafunctional habits and other characteristics related to the overall health of children was also sent. The examiner did not interfere during questionnaire completion. 


\section{Examiner calibration}

Three examiners were properly calibrated prior to clinical examination. The calibration process included the examination of occlusion in 24 children, performed twice with a 15-day interval in between. Data were subjected to Kappa statistics (K) for analysis of reproducibility. An index greater than $0.81 \mathrm{~K}$ and Pearson correlation coefficient (Rs > 0.90) were calculated. Results revealed excellent intra and inter-examiner reliability.

\section{Clinical examination}

All clinical examinations were performed in the school environment with the children sitting comfortably and facing abundant source of artificial light. First, they were asked to perform maximum mouth opening and then occlude in maximum intercuspation (MIH) for data collection.

To assess transverse posterior relationship between upper and lower dental arches, the following criteria were applied: Absent posterior crossbite (when the palatal cusps of upper posterior teeth occluded in the groove of mandibular posterior teeth), and presence of posterior crossbite (when the buccal cusps of upper posterior teeth occluded in the central sulcus of lower teeth, thereby establishing a transverse or inverted cross relationship on the back). Subsequently, both unilateral crossbites, whether with shift or true, as well as bilateral ones, were included.

\section{Questionnaire}

A questionnaire ${ }^{13}$ comprising standardized questions about patient's history was answered by parents/guardians. ${ }^{17}$ Based on the questionnaire, the presence of bruxism (yes or no), the period in which the child presented the parafunctional habit (daytime, night time or both), and the variables related to the presence of restless sleep (yes or no) as well as headaches (yes or no) were investigated. It is worth mentioning that the examiners did not interfere while the questionnaires were being filled out.

\section{Data analysis}

First, a descriptive statistical analysis of all variables (age, sex, race, posterior crossbite, bruxism, headache and restless sleep) was carried out. Subsequently, analyses of statistical significance were conducted by means of chi-square test in order to investigate possible associations between bruxism and other characteristics (sex, race, posterior crossbite, headache and restless sleep). The same test investigated a potential association between posterior crossbite, headache and restless sleep. At last, a logistic regression model was applied for the presence of bruxism, thus presenting the Odds Ratio (OR). The level of significance was set at 5\%, i.e., test results were not statistically significant when P-value was less than or equal to 0.05 .

\section{RESULTS}

Descriptive analysis of variables in the sample

Sample distribution according to age was predominantly composed of children between 4 and 5 years old $(37.3 \%$ and $38.7 \%$, respectively). Regarding patients' sex, the sample was very well divided and comprised 434 females (49.7\%) and 439 males (50.3\%). As for race, most children had brown skin (pardo) (58\%), whereas only $0.4 \%$ had yellow skin.

The minority showed posterior crossbite, totaling $15.5 \%(\mathrm{n}=135)$ as distributed in Table 1. As for the prevalence of the parafunctional habit of bruxism, 26.5\% of children had the habit at night, 2.2\% during the day and $0.1 \%$ during the night and during the day, thereby representing a total of $28.8 \%$ of children with bruxism. Out of the total sample, $21.8 \%(\mathrm{n}=190)$ reported having headaches while $36.1 \%(\mathrm{n}=315)$ claimed to have restless sleep.

\section{Association between bruxism and other variables}

To assess a potential association between the presence of bruxism and other variables, the sample was divided as follows: "No" (when the child did not have bruxism) and "Yes" (when children showed signs of bruxism at night and/or day). The variable posterior crossbite was also treated in a similar way: "Absent" (when the child did not have posterior crossbite) and "Present" (when the child presented any type of posterior crossbite).

According to Table 2, the prevalence of bruxism was higher for males (30.5\%) in comparison to females (27\%). Likewise, black-skin children had higher prevalence $(36.1 \%)$ when compared to other races. Among children with no posterior crossbite, 
Table 1 - Sample distribution according to posterior crossbite (PCB)

\begin{tabular}{|c|c|c|c|c|c|c|c|}
\hline PCB & Absent & Bilateral & Unil. shift R & Unil. shift L & Unil. true. R & Unil. true. L & Total \\
\hline$n$ & 738 & 19 & 53 & 28 & 21 & 14 & 873 \\
\hline$\%$ & 84.5 & 2.2 & 6.1 & 3.2 & 2.4 & 1.6 & 100 \\
\hline
\end{tabular}

Table 2 - Sample distribution according to the presence of bruxism and variables of sex, posterior crossbite, headache, restless sleep and race.

\begin{tabular}{|c|c|c|c|c|c|c|c|c|c|c|c|c|c|c|c|c|c|c|c|c|c|c|c|c|}
\hline \multirow{3}{*}{$\frac{\mathrm{E}}{\frac{5}{x}}$} & \multicolumn{4}{|c|}{$\operatorname{Sex}$} & \multicolumn{4}{|c|}{ Posterior crossbite } & \multicolumn{4}{|c|}{ Headache } & \multicolumn{4}{|c|}{ Restless sleep } & \multicolumn{8}{|c|}{ Race } \\
\hline & \multicolumn{2}{|c|}{ Female } & \multicolumn{2}{|c|}{ Male } & \multicolumn{2}{|c|}{ Absent } & \multicolumn{2}{|c|}{ Present } & \multicolumn{2}{|c|}{ No } & \multicolumn{2}{|c|}{ Yes } & \multicolumn{2}{|c|}{ No } & \multicolumn{2}{|c|}{ Yes } & \multicolumn{2}{|c|}{ Yellow } & \multicolumn{2}{|c|}{ White } & \multicolumn{2}{|c|}{ Black } & \multicolumn{2}{|c|}{ Brown } \\
\hline & $n$ & $\%$ & $n$ & $\%$ & $n$ & $\%$ & $n$ & $\%$ & $n$ & $\%$ & $n$ & $\%$ & $n$ & $\%$ & $n$ & $\%$ & $n$ & $\%$ & $n$ & $\%$ & $n$ & $\%$ & $n$ & $\%$ \\
\hline No & 317 & 73 & 305 & 69.5 & 510 & 69.1 & 112 & 83 & 505 & 73,9 & 117 & 61.6 & 432 & 77.4 & 190 & 60.3 & 4 & 100 & 225 & 74.5 & 39 & 63.9 & 354 & 70 \\
\hline Yes & 117 & 27.0 & 134 & 30.5 & 228 & 30.9 & 23 & 17 & 178 & 26.1 & 73 & 38.4 & 126 & 22.6 & 125 & 39.7 & 0 & 0 & 77 & 25.5 & 22 & 36.1 & 152 & 30 \\
\hline Total & 434 & 100 & 439 & 100 & 738 & 100 & 135 & 100 & 683 & 100 & 190 & 100 & 558 & 100 & 315 & 100 & 4 & 100 & 302 & 100 & 61 & 100 & 506 & 100 \\
\hline
\end{tabular}

the percentage of bruxism (30.9\%) was higher than children with posterior crossbite (17\%). As for headaches, 38.4\% reported headache and showed signs of bruxism, whereas $26.1 \%$ reported having no headache even though they showed signs of bruxism. Children with restless sleep presented a higher percentage of bruxism (39.7\%) in comparison to those who did not report restless sleep (22.6\%).

Table 3 presents the results of the chi-square test with significance level set at 5\%. Results show a significant association between posterior crossbite $(p=0.0015)$, headache $(p=0.0012)$ and restless sleep $(\mathrm{p}<0.0001)$.

\section{Association between posterior}

\section{crossbite, headache and restless sleep}

Table 4 shows the result of sample distribution according to the presence of posterior crossbite, headache and restless sleep. Table 5 shows the result of sample distribution according to the presence of headache and restless sleep. A total of $31.7 \%$ of children who had restless sleep also had headaches. This represents nearly the double if compared to children who did not have restless sleep (16.1\%). The chisquare test showed that there was only significant association between headache and restless sleep with $\mathrm{p}<0.0001$ (Table 6).

\section{Logistic regression model for} the presence of bruxism

A logistic regression model was applied for the presence or absence of bruxism (Table 7). Children without posterior crossbite were 2.2 times more
Table 3 - Chi-square test results

\begin{tabular}{cc}
\hline \multicolumn{1}{c}{ Chi-square test } \\
\hline Comparison with bruxism & P-value \\
\hline Sex & 0.2762 \\
\hline Race & 0.1592 \\
\hline Posterior crossbite & $0.0015^{\star}$ \\
\hline Headache & $0.0012^{\star}$ \\
\hline Restless sleep & $0.0001^{\star}$ \\
\hline
\end{tabular}

*Significant at $5 \%$

Table 4 - Sample distribution according to the presence of posterior crossbite associated with headache and restless sleep.

\begin{tabular}{ccccccccccc}
\hline & \multicolumn{3}{c}{ Headache } & \multicolumn{3}{c}{ Restless sleep } \\
Posterior & \multicolumn{3}{c}{ No } & \multicolumn{2}{c}{ Yes } & \multicolumn{3}{c}{ No } & \multicolumn{2}{c}{ Yes } \\
crossbite & n & $\%$ & n & $\%$ & n & $\%$ & n & $\%$ \\
& Absent & 579 & 84,8 & 159 & 83,7 & 471 & 84,4 & 267 & 84,8 \\
\hline Present & 104 & 15,2 & 31 & 16,3 & 87 & 15,6 & 48 & 15,2 \\
\hline Total & 683 & 100 & 190 & 100 & 558 & 100 & 315 & 100 \\
\hline
\end{tabular}

Table 5 - Sample distribution according to the presence of headache and restless sleep.

\begin{tabular}{|c|c|c|c|c|}
\hline \multirow{3}{*}{ Headache } & \multicolumn{4}{|c|}{ Restless sleep } \\
\hline & \multicolumn{2}{|c|}{ Absent } & \multicolumn{2}{|c|}{ Present } \\
\hline & $\mathbf{n}$ & $\%$ & $n$ & $\%$ \\
\hline Absent & 468 & 83.9 & 215 & 68.3 \\
\hline Present & 90 & 16.1 & 100 & 31.7 \\
\hline Total & 558 & 100 & 315 & 100 \\
\hline
\end{tabular}

Table 6 - Chi-square test results

\begin{tabular}{cc}
\hline & Chi-square test \\
\hline Comparison & P-value \\
\hline PCB X headache & 0.7997 \\
PCB X restless sleep & 0.9671 \\
Headache $X$ restless sleep & $<0.0001^{\star}$ \\
\hline
\end{tabular}

*Significant at $5 \%$ 
Table 7 - Results of logistic regression model applied for the presence of bruxism.

\begin{tabular}{|c|c|c|c|c|}
\hline \multirow{2}{*}{ Characteristic } & \multirow{2}{*}{ Chance ratio } & \multicolumn{3}{|c|}{$95 \%$ confidence interval } \\
\hline & & Lower limit & Upper limit & P-value \\
\hline \multicolumn{5}{|l|}{ Posterior crossbite } \\
\hline Present & 1.0 & \multirow{2}{*}{1.4} & \multirow{2}{*}{3.6} & \multirow{2}{*}{0.0011} \\
\hline Absent & 2.2 & & & \\
\hline \multicolumn{5}{|l|}{ Headache } \\
\hline No & 1.0 & \multirow{2}{*}{1.1} & \multirow{2}{*}{2.2} & \multirow{2}{*}{0.0148} \\
\hline Yes & 1.5 & & & \\
\hline \multicolumn{5}{|l|}{ Restless sleep } \\
\hline No & 1.0 & \multirow{2}{*}{1.6} & \multirow{2}{*}{2.9} & \multirow{2}{*}{$<0.0001$} \\
\hline Yes & 2.1 & & & \\
\hline
\end{tabular}

likely to have bruxism in comparison to children with posterior crossbite. Children who complained of having headaches were 1.5 times more likely (50\% more) to develop bruxism, in comparison to those who did not have headaches. Children with restless sleep have 2.1 more chances to develop bruxism, in comparison to children with peaceful sleep.

\section{DISCUSSION}

The prevalence of the parafunctional habit of bruxism in deciduous dentition has been the subject of some recent epidemiological studies. However, lack of uniformity and standardization of criteria to assess bruxism in children have resulted in a wide variation of its prevalence. ${ }^{17,22,25,28}$

The actual occurrence of bruxism in children cannot be easily registered because the presence of wear facets observed during clinical examination may indicate only a history of bruxism which may no longer be occurring at the time of evaluation. On the other hand, the beginning of the habit may not yet have caused the tooth to show signs of wear. Thus, although being subjective, the method of interviewing the children's parents is considered trustworthy to assess the prevalence of this habit, as it reflects the existence of dental noises produced by the child and which are actually perceived by parents. Therefore, even though prevalence was underestimated, the occurrence of false-positives is almost eliminated. ${ }^{29}$

The methods employed herein included a questionnaire answered by parents and/or guardians and followed a similar standard used in other studies. $., 13,14,17,30$ The difficulty in diagnosing this parafunctional disturbance is widely known ${ }^{29}$ even when diagnosis is based on polysomnography exams which were not performed in this sample. Such an exam becomes even more limited when dealing with children at the stage of primary dentition.

Results obtained herein showed a high prevalence of the parafunctional habit of bruxism, thus corroborating results of previous studies..$^{11,16,17,18,24,30}$ However, some studies ${ }^{21,27}$ revealed even higher occurrences of around 45\% whereas others revealed much lower occurrences as low as $6.4 \%$ in Turkey ${ }^{1}$ and $11 \%$ in India. ${ }^{5}$ It can be supposed that the origin of these differences (regarding the prevalence of bruxism in children) is possibly related to lack of uniformity in methodological research, cultural differences between countries, or even a variety of age groups.

Regarding patients' sex, some studies show that the parafunctional habit of bruxism in children has prevailed for males, ${ }^{14,17,18}$ which was also found in this study. However, a study of Mexican children detected the presence of bruxism in $6 \%$ in female population compared to $1.5 \%$ in male population. ${ }^{12}$ Other studies found no significant differences regarding sexual dimorphism. ${ }^{5,7,9,28}$

In the present study, the majority of children with bruxism did not present posterior crossbite when assessed statistically. However, the results support statistical analysis, thereby giving significance to factors of bruxism, headache and restless sleep. Bruxism is often associated with patient's emotional state and is more common among anxious children. ${ }^{6,23}$

When the chi-square test was applied, the only factors showing a statistically significant association were headache and restless sleep. Nevertheless, posterior crossbite was 
not significantly associated with headache and restless sleep. These data confirm what the literature already proves: There is a correlation between the presence of restless sleep in children with headache. ${ }^{8,10}$

The logistic regression model showed that children without posterior crossbite were 2.2 more likely to have bruxism, in comparison to children with posterior crossbite. Children who complained of headache were 1.5 times more likely to develop bruxism, in comparison to those who did not complain of headaches. Also, children with restless sleep were 2.1 more likely to have bruxism, in comparison to children with peaceful sleep.

Researchers believe bruxism is strongly correlated with children's emotional state ${ }^{6,8,10,17,23}$ (anxiety, hyperactivity, restless sleep), which was also considered in this paper. Additionally, according to some studies, ${ }^{4,14,18,20,21,28}$ children's general health, occurrence of malocclusion (absent, mild, moderate and severe) and the presence of other parafunctional oral habits can also be paired with bruxism. However, in contrast to these studies, the results of the present study showed no significant relationship between the presence of bruxism and posterior crossbite, i.e., the occlusal factor.

In this context, the combination of several etiologic factors present in a single individual greatly increases the likelihood of bruxism in children. Furthermore, its high prevalence is being considered an intrinsic problem of modern society. Thus, different treatment modalities available nowadays should be individualized for each patient.

Early diagnosis is important to reduce the consequences of this parafunctional activity. Clinician's treatment protocol should be directed towards reducing psychological stress and treating signs and symptoms, since bruxism cannot be permanently eliminated. One should opt for conservative therapy, with reversible and not invasive control as well as continuous follow-up. Due to its multifactorial etiology, bruxism treatment should involve professionals such as pediatricians, psychologists, pediatric dentists and otolaryngologists.

\section{CONCLUSIONS}

The parafunctional habit of bruxism was prevalent in $28.8 \%$ of the total sample studied. There was no significant relationship between this parafunctional habit and the transverse plane of occlusion. However, headache and restless sleep were significantly associated with bruxism in children. 


\section{REFERENCES}

1. Agargun MY, Clli AS, Sener SS, Bilici M, Ozer OA, Selvi Y, Karacan E. The prevalence of parasomnias in preadolescent School-aged Children: a Turkish sample. Sleep. 2004:27(4):701-5

2. Ahmad R. Bruxism in children. J Pedod. 1986;10(2):105-26

3. Ângeles ET, Gáldos AC, Sanches LR, Martinez CS. Prevalência de bruxismo em pacientes de primeira vez em el Instituto Nacional de Pediatria. Acta Pediatr Méx 2003;24(2):95-3.

4. Antonio AG, Pierro VSS, Maia LC. Bruxism in children: a warning sign for psychological problems. J Can Dent Assoc. 2006;72(2):155-60.

5. Bharti B, Malhi P, Kashyap S. Patterns and problems of sleep in school going children. Indian Pediatr. 2006:43(1):35-8.

6. Cariola TC. O desenho da figura humana de crianças com bruxismo. Bol Psicol. 2006;56(124); 37-52

7. Ferreira AM, Clemente V, Gozal D, Gomes A, Silva FC. Snoring in portuguese primary school children. Pediatrics. 2000;106(5):64.

8. Francesco DCR, Passerotii G, Paulucci B, Miniti A. Respiração oral na criança: repercussões diferentes de acordo com o diagnóstico. Rev Bras Otorrinolaringol. 2004;70(5):665-70

9. Fukumizu M, Kaga M, Kohyama J, Hayes MJ. Sleep-related nighttime crying (yonaki) in Japan: a community- based study. Pediatrics. 2005;115(1):217-24

10. Gorayeb MAM, Gorayeb R. Cefaléia associada a indicadores de transtornos de ansiedade em uma amostra de escolares de Ribeirão Preto, SP. Arq Neuropsiquiatr. 2002;60(3B):764-8

11. Gregório PB, Athanazio RA, Bitencourt AGV, Neves FBCS, Hora F. Sintomas da síndrome de apnéia-hipopnéia obstrutiva do sono em crianças. J Bras Pneumol. 2008;34(6):356-61

12. Jaime MEM. Frequencia de maloclusiones y su associación com hábitos perniciosos em uma población de niños mexicanos de 6 a 12 años de edad. Rev ADM. 2004:61(6):209-14

13. Junqueira TH, Nahás-Scocate AC, Valle-Corotti KM, Conti AC, Trevisan S. Association of infantile bruxism and the terminal relationships of the primary second molars. Braz Oral Res. 2013;27(1):42-7.

14. Liu X, Ma Y, Wang Y, Rao Y. Brief report: an epidemiologic survey of the prevalence of sleep disorders among children 2 to 12 years old in Beijing, China. Pediatrics. 2005;115(1):266-8.

15. Loos PJ, Aaron GA. Standards for management of the pediatric patient with acute pain in the temporomandibular joint or muscles of mastication. Pediatric Dent. 1989:11(4):331

16. Mendes LR, Fernandes A, Garcia FT. Hábitos e perturbações do sono em idade escolar. Acta Pediatr Port. 2004;35:341-7
17. Nahás-Scocate ACR, Trevisan S, Junqueira TH, Fuziy A. Associação entre o bruxismo infantil e as características oclusais, sono e dor de cabeça. Rev Assoc Paul Cir Dent. 2012:66(1):18-22.

18. Ng Dk, Kwok K, Cheung JM, Leung S, Chan CH. Prevalence of sleep problems in Hong Kong primary school children. Chest. 2005;128(3):1315-23.

19. Okeson JP. Temporomandibular disorders in children. Pediatric Dent 1989;11(4):325-9.

20. Pavarina AC, Bussadori CMC, Alencar Jr FGP. Aspectos dos hábitos parafuncionais de interesse para o clínico geral. J Bras Clin Estet Odontol. 1999;3(13):86-90

21. Petit D, Touchette E, Tremblay RE, Boivin M, Montplaisiur J. Dyssomnias and parasomnias in early childhood. Pediatrics. 2007;119(5):1016-25.

22. Pizzol KED C, Carvalho JCQ, Konishi F, Marcomini EMS, Giusti JSM. Bruxismo na infância: fatores etiológicos e possiveis tratamentos. Rev Odontol UNESP. 2006:35(2):157-63.

23. Porto FR, Machado LR, Leite ICG. Variáveis associadas ao desenvolvimento do bruxismo em crianças de 4 a 12 anos. J Bras Odontopediatr Odontol Bebê. 1999;2(10):447-53.

24. Reimão R, Lefevre A B, Diament AJ. Prevalência de distúrbios do sono na infância. Pediat. 1983:5:49-55.

25. Rodrigues KC, Ditterich RG, Shintcovsk RL, Tanaka O. Bruxismo: uma revisão da literatura. Publ UEPG Ci Biol Saúde. 2006;12(3):13-21.

26. Santos ECA, Bertoz FA, Pignatta LMB, Arantes FM. Avaliação clínica de sinais e sintomas da disfunção temporomandibular em crianças. Rev Dental Press Ortod Ortop Facial. 2006:11(2):29-34

27. Serra-Negra JMC, Vilela LC, Rosa AR, Andrade ELSP, Paiva SM, Pordeus IA Hábitos bucais deletérios: os filhos imitam as mães na adoção destes hábitos? Rev Odonto Ciênc. 2006:21(52):146-52.

28. Shinkai RSA, Santos LM, Silva FA, Santos MN. Contribuição ao estudo da prevalência de bruxismo excêntrico noturno em crianças de 2 a 11 anos de idade. Rev Odontol Univ São Paulo. 1998:12(1):29-37.

29. Vanderas AP, Manetas KJ. Relationship between malocclusion and bruxism in children and adolescents: a review. Pediatric Dent. 1995;17(1):7-12

30. Villa MT, Torres AM, Soto BB, Gomar MR, Langa MJS, Sierra YAIU. Relación entre el trastorno por défict de atención e hiperactividad y los trastornos del sueño. Resultado de um estúdio epidemiológico em la población escolar de la ciudad de Gandía. An pediatr (barc). 2008:69(3):251-7. 